\title{
Através da noite, de Stig Sæterbakken (fragmento)
}

\author{
Guilherme da Silva Braga'
}

\section{Apresentação}

Stig Sæterbakken nasceu em 1966 em Lillehammer, onde mais tarde viria a dirigir o importante festival literário que ocorre na cidade e atrai autores, editores e visitantes do mundo inteiro à Noruega. Teve uma produção bastante eclética, que abarca ensaios (Der jeg tenker er det altid morkt, Essays i utvalg), fragmentos autobiográficos (Ikeke noe av dette handler om meg) e naturalmente romances (Gjennom natten, Usynlige Hender, Ikke forlat meg). Entre esses últimos encontram-se obras altamente experimentais como Sauermugg - resultado de um processo criativo extremo, que consistiu em escrever uma narrativa romanesca completa a partir da estaca zero no inverossímil prazo de uma semana (a gênese dessa obra foi acompanhada pelo cineasta Morten Hovland e transformada no interessantíssimo documentário Forfatteren - Sauermugg blir til). Morreu em 2012 aos 46 anos, vítima de suicídio.

A obra de Sæterbakken é marcada pelo desespero dos protagonistas e por uma atmosfera palpável de escuridão; os personagens com frequência veem-se em situações que não admitem qualquer tipo de resolução que não a tragédia. $\mathrm{O}$ romance ora apresentado - Gjennom natten (2011), ou "Através da noite", foi a última obra de ficção que Sæterbakken legou à posteridade. Na obra, o dentista

1 Guilherme da Silva Braga é mestre e doutor em Estudos de Literatura pela Universidade Federal do Rio Grande do Sul (Brasil) e concluiu um pós-doutoramento na área de tradução literária na Universidade de Coimbra (Portugal). Traduziu mais de 50 volumes publicados de autores clássicos e contemporâneos a partir do inglês, do norueguês e do sueco para as principais editoras brasileiras. Ministrou oficinas de tradução literária no Brasil, na Irlanda e em Portugal, e em 2016 foi indicado ao Prêmio Jabuti de melhor tradução literária publicada no Brasil. 
Karl Meyer - casado com Eva e pai do casal de adolescentes Ole-Jakob e Stine - começa um flerte despretensioso com uma mulher chamada Mona, porém o relacionamento entre os dois logo evolui para um jogo erótico do qual não parece haver escapatória: Meyer por fim leva a aventura extraconjugal às últimas consequências. Arrependido, mais tarde confessa a traição a Eva, porém na esteira do abalo familiar causado por essa revelação Ole-Jakob suicida-se em um acidente intencional de carro. Durante o luto pela morte do filho, Meyer ouve do amigo e romancista Boris Snopko a história acerca de uma misteriosa casa na Eslováquia, na qual - desde que se tenha os contatos certos - os visitantes podem entrar mediante o pagamento de uma assombrosa quantia em dinheiro e ver-se frente a frente com os piores temores. A princípio, Meyer imagina que essa seria mais uma criação ficcional do amigo, porém logo decide procurar essa casa "onde a esperança transforma-se em merda". Gjennom natten narra a história dessa terrível busca.

\section{Edição consultada:}

SÆTERBAKKEN, Stig. Gjennom natten. Cappelem Damm: Oslo, 2012. 


\section{I}

\section{Helvetes jævla dritt}

Stig Saterbakken

Sorg kommer i så mange former. Den er som et lys som slås av og på. Den er der, og er uutholdelig, og så forsvinner den, fordi den er uutholdelig, fordi det ikke går an å ha den der hele tiden. Man fylles og tømmes. Tusen ganger om dagen glemte jeg at Ole-Jakob var død. Tusen ganger om dagen husket jeg det plutselig. Begge deler var uutholdelig. Å glemme ham var det verste jeg kunne gjøre. Å huske ham var det verste jeg kunne gjøre. En kulde kom og gikk. Men aldri varme. Det fantes bare kulde og fravær av kulde. Som å stå med ryggen mot havet. Iskalde ankler hver gang en bølge slo inn. Så rant den vekk. Så kom den tilbake.

Mens jeg sto slik, gikk solen ned, og det ble natt, og det er natten som siden har vart.

I dagene etter begravelsen gjorde jeg ikke stort, bortsett fra å se på tv. Som med et håp om at hvis jeg bare satt slik, uten å røre meg, fullt og helt konsentrert om det som foregikk på skjermen, ville smerten etter hvert forsvinne, da ville jeg bli en del av den andre virkeligheten, der smerte ikke finnes. En kveld så jeg en Rosa Panter-film. Det var den hvor Clouseau (Peter Sellers) under avhøret av en velstående engelsk familie setter fast hånden $\mathrm{i}$ hansken til en gammel rustning og forvandler stuen til en slagmark før han er ferdig med Poirot-oppsummeringen sin. Og plutselig var ikke latteren til å holde tilbake. Jeg som var sikker på at jeg aldri ville le igjen, jeg lo så det kjentes som jeg hadde et dyr inni meg som prøvde å spise seg ut. Jeg måtte skru av tv-en til slutt, hadde jeg sett filmen til ende, ville jeg ha eksplodert.

«Den helvetes jævla tv-en!» En kveld jeg sto ute og røkte i pausen mellom to serier jeg var begynt å følge med på, så jeg skyggen til Eva over gårdsplassen, den fór forbi som et skrømt. Så hørte jeg noe skrammel fra garasjen, men tenkte ikke noe mer over det. Da jeg kom inn i stuen igjen, var tv-en knust, økseskaftet sto ut av skjermen, som lignet en seig svart masse mer enn splintret glass. Selv sto hun midt på gulvet og hveste, som om hun hadde tungt for å puste. Heldigvis - eller uheldigvis - var Stine der, hun satt med armene rundt knærne og gråt, slik at det ikke kunne bli snakk om noe annet fra min side enn å gjøre hva jeg kunne for å roe henne. Jeg tenkte på det mens jeg satt og holdt rundt henne, hvordan det 
hadde vært et av mine tilbakevendende klagemål $i$ alle år, alle timene Eva tilbragte foran tv-en, hvordan det hadde gått meg på nervene mang en gang, tiltaksløsheten det vitnet om, det evinnelige tidsfordrivet, forsvart av henne som avkobling, livsnødvendig, hvis jeg forsto henne rett, i vente på en ny dyst, som om arbeidet hennes var det eneste virkelige, resten av dagene ikke ment for annet enn å samle krefter for å bli i stand til å vende tilbake til det igjen, som om hun hadde gitt opp å være den hun egentlig var når hun var hjemme sammen med meg, sammen med oss, at dette var blitt noe hun sparte til arbeidsdagene, akkurat som det ikke var nødvendig å anstrenge seg lenger, at jobben med meg var gjort, i motsetning til jobben med de andre: alt dette kunne komme vellende opp i meg bare ved synet av henne halvt liggende i sofaen med ansiktet badet i fjernsynsskjermens altoppslukende skimmer.

Etter at tv-en var knust, ble det lange spaserturer i stedet for CSI Miami og Dexter og gamle klassikere på TCM. Jeg valgte helst ruter jeg ikke hadde gått før og oppdaget til og med noen stier jeg ikke visste om. På noen av dem fikk jeg det for meg at det ikke hadde vært folk på mange år, grenene vokste langt inn på stien og dasket mot jakken når jeg passerte. Av og til, når det var mørkt, kunne jeg få øye på et lys, flere lys, bitte små på grunn av avstanden, men likefullt synlige gjennom en uendelig rad åpninger i bladverket. Et blinklys på en bil dukket for eksempel opp rett foran meg, like etterpå et trafikklys som skiftet fra gult til grønt, langt i det fjerne.

Hver gang jeg kom hjem, sto jeg litt i gangen og lyttet før jeg gikk inn, for å høre om noen gråt.

Det var så mye jeg ikke forsto. Brutaliteten i alt: i butikken, måten folk skjøv handlevognene foran seg på, måten de rotet rundt i frysedisken på, eller de sto borte ved grønnsakshyllene og snakket høylydt sammen, som om ingenting var skjedd. Ute på gaten, den infernalske trafikken, bilførerne som peiset på alt hva remmer og tøy kunne holde og som lå på hornet straks noen foran i køen brukte litt for lang tid ut av lyskrysset. Skoleungdom som kom i store flokker og som så ut som de holdt på å sprekke av lykke. Bråk overalt, biler som kjørte, mennesker som snakket, høy musikk. Alt for å overdøve det veldige sluket av stillhet som ville ha åpnet seg hvis alle hadde sluttet med det de drev med. Mennesker som snakket, men ikke én av dem om Ole-Jakob. Helvetes jævla drittsekker. Hvordan var det mulig? Hva hadde de å snakke om, nå da han var død?

Verden hånte oss. Den hånte Stine, som skulle vært en del av det yrende mylderet, som var ment å skulle utgjøre en brikke i dette store spillet ennå i mange år, som bare så vidt hadde begynt da hun ble utestengt fra det. Enda jeg visste at hun ville bli det igjen om en stund. Og at det høyst sannsynlig ville gå bra, med 
tiden til hjelp. «Med tiden til hjelp»: en hån, dét òg. Tanken på at det ville gå bra. At hun ville klare det. At hun om ikke altfor lenge igjen ville svinge seg i valsen, smile og le, tulle og tøyse, fullt og helt dedikert til det evinnelige fjaset en tilværelse blant jevnaldrende besto av, som det var meningen at den skulle bestå av, som en nødvendig strekning på veien frem til hennes voksne jeg. Alt dette skulle hun vende tilbake til, med friskt mot, det var bare et spørsmål om tid. Det som tynget henne skulle ristes av, ikke helt, men nok til at hun kunne fortsette å leve blant sine, nok til at hun atter kunne svinge seg i valsen sammen med dem.

De første dagene sa hun ingenting. Hva var det å si? Hver gang jeg eller Eva, i hver vår redsel for hvordan hun hadde det, prøvde å få noe ut av henne, ble hun stram i ansiktet, hard som en stein, eller hun begynte å gråte, noe som til slutt gjorde oss mer redde for å prøve enn for hva vi ville få vite dersom vi lyktes med det. Da hun så endelig brøt tausheten, var det ikke med annet enn skjellsord og bannskap. HELVETES JÆVLA DRIT'T, var det første jeg hørte henne si. Det var som å høre Eva, stemmen til forveksling lik. Begravelsesagenten hadde vært hjemme hos oss for å diskutere de siste detaljene, jeg hadde akkurat lukket døren bak ham da jeg hørte Stine inne fra kjøkkenet. HELVETES JÆVLA DRITT! Jeg kjente et stikk av glede. Første livstegn fra en vi trodde var blitt borte for oss! Jeg gikk inn til dem. Stine hadde reist seg, det bare veltet ut av henne, det så ut som hun kastet opp, den ene grovheten verre enn den andre, beskyldningene haglet. Eva strakte ut armen og fikk så vidt tak i henne, før hånden ble slått tilbake. Jeg så på dem og så hvor like de var blitt, mor og datter. Stine hakket vakrere, som om hun hadde tatt med seg ansiktet til Eva og perfeksjonert det. Og jeg tenkte på hvor ofte hun, da hun var mindre, hadde sittet taus og lyttet til broren mens han la ut om alt mellom himmel og jord, hvordan hun satt og observerte ham og beundret ham, hvordan hun hadde overlatt snakkingen til ham, sendt ham foran seg ut $\mathrm{i}$ verden, slik at han kunne fortelle henne om den.

Hele tiden prøvde jeg å tenke på noe annet, men fikk det ikke til, konsentrasjonen glapp, tankene var som dårlige tegninger, de måtte rives i stykker med én gang.

Eva begynte ikke å gråte før det var gått flere uker. Men en dag jeg kom hjem fra en av de helvetes jævla turene mine og hørte støvsugeren inne fra stuen, fant jeg henne i en bylt på gulvet, hulkende, som om hun hadde grått ut alt som var og ikke hadde mer å gi, men allikevel ikke klarte å stoppe. Jeg heiste henne opp, hun var tung som en kraftig mann og holdt støvsugerrøret $i$ et så hardt grep at jeg måtte bryte opp én og én finger for å få det løs. Jeg dro henne opp i sofaen og la hodet hennes i fanget mitt. Noen store våte flekker syntes på gulvet der hun hadde ligget. Jeg strøk henne over håret og hysjet på henne. «Så, så,» sa jeg, som 
til et barn. «Vi skal klare det. Vi skal klare det.» Men jeg hadde ikke før sagt det, så kjente jeg hulheten i det, hulheten i det jeg akkurat sa, i det jeg hadde overtalt meg selv til å ville enda en gang - akkurat som da jeg vendte tilbake etter «eventyret mitt» - hulheten $i$ alt som hadde vært, alt som var, alt som kom til å være. Og jeg visste at uansett hva jeg sa til henne, uansett hva jeg enda en gang fikk henne til å tro på, så kom det før eller siden til å bli avslørt som tomme løfter, som lovnader uten dekning i noe, uten forbindelse til den virkeligheten som nok en gang ville komme til å ødelegge for oss. Ennå lå hun bare der, uten å røre seg. Og jeg kjente hvordan kroppen hennes stivnet mens jeg satt og holdt rundt henne og støvsugeren fortsatte sitt ville brøl mot veggene. Hva skal vi gjøre, tenkte jeg. Når dette er over. Når vi er ferdige med all sorgen. Når vi har kommet oss igjennom det, hvis vi gjør det, hva i all verden skal vi foreta oss da.

Eva hadde vært der inne og ryddet, visste jeg, selv hadde jeg ikke orket å gå inn der, jeg vet ikke hvorfor. Av frykt for at han ville være der, i alt som var hans? Til slutt tynget det meg slik at det føltes som jeg ikke kunne gjøre noe annet før jeg hadde gjort det. Jeg ventet til en dag jeg var alene i huset. Enda ble jeg stående lenge foran døren. Mens jeg sto der gikk det opp for meg hvor lenge det var siden jeg hadde vært på rommet hans, ikke en eneste gang etter at jeg flyttet hjem igjen, ikke siden før jeg forlot dem for å leve sammen med Mona. Jeg banket på først. Så åpnet jeg døren og gikk inn.

Eva hadde ikke ryddet. Alt var slik han hadde etterlatt det, hauger med klær på gulvet, headset og håndklær og CD-er og blader og tomme energidrikkbokser, ledninger, en deodorant, en sprayflaske, spillkonsollen som en liten klippe midt $\mathrm{i}$ virvelen av rot. Skapdøren var åpen, en kurv med undertøy dratt ut. I vinduskarmen sto en gruppe uniformerte skjeletter på geledd, håndmalte, forseggjorte, med en svart firkantet plastbrikke under føttene på hver enkelt. Det eneste, slo det meg, som bar preg av orden. Ledningen til spillkonsollen hadde fått en knekk i leddet rett over kontakten, da jeg bøyde meg ned for å trekke den ut av støpselet, gnistret det til i bruddet der litt av kobberet syntes. Skremt slik et barn ville blitt, lot jeg den være $i$.

Jeg satte meg på sengen. Dynen kjentes fuktig, det ene hjørnet var misfarget. Jeg kikket opp i taket. Alle bildene og plakatene jeg hadde sett der en gang var borte. Men det sto skrevet noe der, med sprittusj, butte blokkbokstaver: JEG VIL IKKE VÅKNE I MORGEN. På lampekuppelen var det festet et klistremerke som var begynt å smelte, den øverste delen hadde rullet seg sammen til et lite rør. Jeg løftet på dynen. Under den lå et sjokoladepapir og en sokk. Jeg tok sokken i hånden. Den var hvit med en blå kant øverst. Under var den svart av møkk, noen gresstrå hang fremdeles fast i det finmaskede stoffet. Jeg lurte på hvor mange 
ganger jeg hadde sagt til ham og Stine at de ikke skulle gå ute på sokkelesten. Og jeg tenkte på det jeg også hadde sagt mange ganger, at jeg har sagt det tusen ganger, noe de begge elsket å konfrontere meg med. Akkurat i dette tilfellet hadde jeg imidlertid mine ord i behold. Jeg holdt sokken opp til nesen. Tåfislukten fikk det til å svimle for meg. Jeg ble sittende og snuse. Jeg klemte sokken mot ansiktet og pustet gjennom den. Det kjentes som jeg ble dratt under i et dragsug, som jeg forsvant ned i alt rotet hans. Det kjentes vidunderlig godt.

En dag gikk jeg på en buss og ble med hele veien ut av byen og tilbake igjen. En liten stund døste jeg, da jeg våknet ante jeg ikke hvor jeg var. Jeg satt med pannen mot vinduet, som dirret svakt $\mathrm{i}$ takt med motorduren, og prøvde å holde tankene konsentrert om det jeg så, jeg klamret meg fast med øynene til bygninger og kjøretøy i landskapet som fór forbi og diktet opp historier i farten om hvem som eide dem. Et sted svingte bussen rundt og forbi en grå bil med et lass grus på lasteplanet. Øverst i en skråning lå en morene oppe i dagen med planterøtter på kryss og tvers. En hvit genser hengt til tørk utenpå et hvitt laken lignet et gammelt ansikt med trette øyne og skjev munn. Jeg så også flere gjerder og drivhus, det ene i verre forfatning enn det andre, reist med det formål, kunne det virke som, å skulle forfalle. Men da vi nærmet oss de store byggefeltene igjen, var det som alt ble strammet opp, også naturen selv, som alt, mennesker, dyr, planter, derfra og inn til byen la an på å vise seg fra en bedre side. Et ungt par hadde satt seg på setet foran meg, jenta lente hodet mot skulderen til gutten, som av og til bøyde hodet frem og kikket på henne. Jeg merket jeg ble dypt misunnelig på ham, på dem begge. Det var noe så velsignet fredfylt over dem, bekymringsløst innsatt i omgivelser ennå ikke sterke nok til å rokke ved lykken og forelskelsen deres. Overfor disse to, tenkte jeg, har ikke verden noe den skulle ha sagt. Ingenting kan forstyrre dem. De er i likevekt. Kjærligheten og begjæret likelig fordelt, ennå ikke noe spørsmål om hvem av dem som lengter mest. Da jeg var på vei ut, snudde jeg meg mot dem og sa: «Husk dette øyeblikket!» Gutten kvapp, han så helt forskrekket ut, og da bussen kjørte videre, fikk jeg et glimt av dem i vinduet, begge satt og stirret ut på meg som på en som hadde prøvd seg på et eller annet, uten at de skjønte hva.

Jeg tror det var om kvelden samme dag at Boris fortalte meg om det mystiske huset, et sted i Slovakia, han visste ikke hvor, som var slik at hvis man kontaktet rette vedkommende og betalte en tilstrekkelig sum penger, visstnok svimlende høy, fikk man en nøkkel og en lapp med adressen på, samt et tidspunkt, nøyaktig på klokkeslettet en bestemt dato, hvor man, hvis man tok seg inn i huset akkurat da, ville bli konfrontert med sitt livs verste redsler. Enda var det dem, ifølge Boris, som hevdet at de hadde vært der og at de kom ut igjen lette til sinns, kurert for alt som hadde tynget dem, opprømte og glade, uten en eneste angst igjen i 
kroppen. De hadde sett det verst tenkelige, etter dét kunne ingenting true dem lenger. Andre, sa han, hadde returnert med heslige, fordreide ansikter, det var slik at noen av deres aller nærmeste hadde problemer med å kjenne dem igjen. Én var helt grå i huden og hadde fått nesen flyttet over på kinnet, og etterpå sa han ikke et ord mer til noen, stengte seg inne på et rom i leiligheten der han bodde og ble der til han døde, bare noen uker senere. En annen skal ha gått fra huset og rett bort til en jernbanelinje og kastet seg ned foran et godstog, som halshugget ham. Noen som oppholdt seg i huset i fem minutter, skal ha kommet ut igjen og trodd fullt og fast at de var blitt holdt innesperret der i flere år. Noen var det også som mente at de ikke hadde merket noe før lenge etterpå, da det helt forferdelige ved tankene de hadde gjort seg mens de var der plutselig hadde gått opp for dem. Og så var det de som sa at det var om å gjøre å holde seg våken mens man var der, at det var til å hanskes med, huset, så lenge man ikke la seg til å sove i det, men falt man først i søvn, var det ingen vei tilbake, da var man fortapt.

Først trodde jeg det var noe han fant på, et slags desperat påhitt i adspredelsens tjeneste, uimottagelig som han sikkert oppfattet meg for konvensjonelle former for trøst. Jeg så det på ham, da han var hos meg, hvordan han lette febrilsk etter noe å si som i det minste for noen minutter kunne ta tankene mine vekk fra det ene som opptok meg, hvor inderlig han ønsket for en stakket stund å erstatte dette ene med noe annet, hva som helst som ikke hadde navnet Ole-Jakob på seg.

Han var ivrig, plapret i vei, utmalte alle detaljer. Mannen man skulle kontakte het Zagreb. Man fant ham, sa Boris, ved å gå på en bar i Bratislava som heter Neusobl, i strøket bak Reduta, som er konserthuset til filharmonien, og opplyse til bartenderen, etter å ha bestilt en Corgo `n, at man ønsket å se det stedet der «håp blir til skit». Det hørtes ut som plotet i en Boris Snopko-roman. Noe jeg i grunnen innerst inne også trodde at det var.

Resten av kvelden satt han og fabulerte rundt hva som mest sannsynlig ville ha møtt ham, om han selv hadde våget seg inn $\mathrm{i}$ «redselens hus». Under normale omstendigheter ville vi ha utesket hverandre om dette. Nå behøvde han ikke spørre. Han verket kanskje etter å gjøre det. Men ettersom svaret ga seg selv, var det vel ikke noe stort offer for ham å la være.

Jeg var ham takknemlig for det. Ikke da, men siden. Alle hans historier. Jeg lyttet ikke til ham, jeg var uimottagelig, han hadde rett, men jeg lyttet allikevel, liksom en del av meg tok vare på det til senere bruk. Der og da irriterte han meg slik at jeg måtte besinne meg for ikke å kaste ham på dør. Komme brasende inn på den måten og prøve å ta ifra meg sorgen! Som om han forstyrret meg under 
en gudstjeneste. Hans pågangsmot var en fornærmelse, hans oppmuntrende ord blasfemiske. Men en ørliten del av meg anerkjente hans bestrebelser og elsket ham for det, at han orket, all den tid han skjønte at ikke noe av det nådde inn, at han både lot meg forbli i min uimottagelighets vold og samtidig gjorde hva han kunne for å frelse meg fra den, at han både lot meg i fred og samtidig ikke.

Jeg tenkte på det etterpå: han må ha følt det som han besøkte en venn i fengsel.

Mitt eksemplar av den ene av bøkene hans som var oversatt til norsk hadde et eseløre på side noen og tredve. Den handlet om et samfunn der man på grunn av overbefolkning hadde innført en lov som ga alle borgere over myndig alder rett til å drepe ett menneske uten å bli straffeforfulgt. Siden, da han var gått over til å skrive på norsk, hadde han lett forgjeves etter noen som ville utgi det. Heller ikke hadde han lyktes med å få oversatt noe mer av det som allerede var utkommet. $\mathrm{Og}$ da han, som en siste utvei, oversatte et av de norske manuskriptene til slovakisk, ville ikke hans gamle forlag ha det heller. Jeg visste ikke om han hadde skrevet noe etter dette, i hvert fall var det som hans livlige fantasi fra nå kun ble brukt til til å dikte opp all verdens forklaringer på refusjonene. I tillegg investerte han enorme ressurser på å rakke ned på alt som ble publisert, enten det var beslektet med hans egne bøker eller ikke. Og om han var i humør til det, beskyldte han dem gjerne for å ha rappet ideene fra ham, enda så fjernt det enkelte ganger hørtes ut fra noe han kunne ha kommet på. Det ble noe av en besettelse for ham. Fordi ingen likte det han skrev, likte han ingen som skrev. Dette med en slik vedvarende intensitet at han antagelig ikke hadde krefter igjen til å produsere noe av det som, dersom det hadde sett dagens lys, det lå som et uuttalt premiss for alle de harde dommene han felte, ville overgått alt.

Da Ole-Jakob var liten, fortalte jeg ham et eventyr som jeg fant på etter hvert som jeg fortalte det, ett kapittel hver kveld, og som jeg siden skrev ned, fordi han maste så, og sendte til et forlag, fordi min søster, som hadde fått snusen i det, mente det ikke kunne skade, og som etter litt bearbeiding ble utgitt under tittelen Prins Uvitende, tilegnet ham som hadde drevet meg til det og som jeg forestilte meg en dag ville lese den høyt for sine barn og stolt vise dem dedikasjonen foran i boken. Eventyret handlet om prins Emmanuel i landet Tekirekki, som ikke vet at han er prins, fordi hans far, kong Sander, som er enkemann, satte ham bort da han var liten for at han skulle få en vanlig oppvekst hos en vanlig familie, gå på vanlig skole, få vanlige venner, kort sagt ikke bli forskjellsbehandlet eller tatt på med silkehansker, inntil han var moden for å bli gjort kjent med sin strålende herkomst. - Herregud, for en dum konge! sa Ole-Jakob, fortvilet over alt gutten ville gå glipp av. 
Imidlertid viser det seg at moren i fosterfamilien, Bellamira, er en heks, som ikke kan få barn og som blir så kjær i gutten at hun vil ha ham selv og derfor kaster en forbannelse over kongen som får ham til å glemme at han har en sønn. Dermed lever de i mange år, både far og sønn, uvitende om hverandre. Og i sin ensomhet takker kongen ja da en fjern slektning, som er konge i et land herjet av borgerkrig, spør ham om hans datter, prinsesse Caroline, kan få bo hos ham til krigen er over. Slik går det til at kong Sander tar til seg og oppdrar Caroline som sitt eget barn og at innbyggerne i Tekirekki, selv om de vet at hun egentlig ikke er det, kommer til å tenke på henne som kongens datter og den rettmessige arving til tronen. Stor oppmerksomhet får også prinsessens kjæledyr, Fredrik Frosk. Ryktene sier at han er en forhekset prins, som hun, den dagen hun blir myndig, skal kysse, slik at hun kan gifte seg med ham. Med andre ord er det sin fremtidige konge folket ser i det sleipe krypet med gullenke og diamanthalsbånd som alltid kommer hoppende to skritt bak yndige Caroline.

Emmanuels fostermor, Bellamira, har en tvillingsøster, Mirabella, som også er heks, men som er snill. Hun er den eneste som er kjent med Bellamiras onde hensikter, fordi hun har en glasskule hvor hun kan se tankene til alle mennesker. Allikevel kan hun ikke gjøre noe for å forhindre det, ettersom Bellamira har kastet en forbannelse også over henne, slik at hun ikke kommer seg ut av huset hun bor i. Hun bestemmer seg derfor for å lokke Emmanuel til seg og avsløre sannheten for ham. Dette gjør hun ved å spille på en magisk harpe (i virkeligheten hennes eget hår, som når akkurat ned til gulvet når hun bikker hodet over til den ene siden, og som hun spenner ved å tråkke med foten på tuppene). Trolldommen virker, Emmanuel våkner og lar seg lede av de deilige tonene, hele veien til heksens hus, som ser ut som et alminnelig hus utenfra, men hvor tak og vegger innvendig er laget av lakris. Mirabella kaster samtidig en forbannelse over huset til fosterforeldrene, slik at tiden der inne står stille, helt til forbannelsen oppheves. Mirabella forteller Emmanuel hvem han egentlig er og viser ham i glasskulen både slottet og faren og alle de andre som bor der. Ved synet av den vakre piken som vandrer rundt $\mathrm{i}$ salene med en frosk i bånd blir prinsen straks forelsket, noe han imidlertid er klok nok til ikke å røpe for sin gode hjelper.

Men flere farer står i veien for familiegjenforeningen. På slottet bor nemlig også kongens rådgiver, en grønn puddel ved navn Madagaskar - egentlig en rosa gris, men forandret til en puddel, fordi Ole-Jakob syntes griser var ekle - som en trollmann fra Madagaskar en gang fikk til å gå på to ben og ga talens bruk, og som nå, etter mange år i kongens tjeneste, har fått smaken for makt og som går med planer om å styrte kongen og forvandle Tekirekki til et diktatur. Statskuppet 
skal han gjennomføre ved hjelp av et hemmelig våpen, fire superhelter, nærmere bestemt, som kan trylles frem fra en magisk kortstokk han stjal fra trollmannen som forvandlet ham.

Det er med andre ord ikke få utfordringer Prins Uvitende står overfor: først å ta seg inn på det godt bevoktede slottet og få kontakt med faren og overbevise ham om blodsbåndet, dernest avsløre og forhindre rådgiverens skumle planer. Med seg på den farefulle ferden trenger han derfor en venn og våpendrager. Mirabella skulle gjerne ha fulgt ham, om hun hadde kunnet. Hun må imidlertid nøye seg med å orkestrere det hele fra sin lakrisduftende husarrest. - Hvordan fär bun mat, bvis det er sainn at hun aldri kan gå ut? - Hvordan tror du? Men i det østre hjørnet av Byparken, under roten på et gammelt eiketre, lever det en pukkelrygget dverg som heter Fabel, som ikke er spesielt modig, men som har den egenskapen at det vokser ut vinger på ryggen hans hver gang han blir redd. Fabel er Mirabellas beste venn og er allerede innviet i farene som truer kongeriket. Første kapittel slutter med at Emmanuel får instrukser av Mirabella om hvordan han kontakter Fabel, for så å bli sendt av gårde med følgende visdomsord: «Frykten gir vinger. Men det er når man lander at den virkelige jobben begynner!»

Emmanuel oppsøker Fabel i den hemmelige grotten under eiketreet. De to enes om en slagplan og starter ferden mot slottet, utrustet med et helt lite arsenal av hjelpemidler, blant annet en såkalt ønskebillett, som virker på den måten at hvis en person holder i den og man roper navnet på et hvilket som helst sted i verden, forsvinner personen dit for aldri mer å vende tilbake. Oppdraget byr imidlertid på mer dramatikk enn noen på forhånd hadde kunnet forestille seg, ikke minst da Madagaskar kommer kongen i forkjøpet og sender ut sine betrodde riddere mot inntrengerne på slottet: Ruter Knekt, bevæpnet med spyd, Hjerter Dame, forførerinnen i egen person, Kløver Konge, bevæpnet med hellebard, og Spar Ess, en kløpper med pisken. - Kult! Trefningene er voldsomme, og mer enn én gang blir Emmanuel reddet av en vettskremt Fabel som tar ham i jakkekraven og flyr ham i sikkerhet. Caroline er den eneste de rekker å fortelle om komplottet, men det går ikke bedre enn at alle tre blir tatt til fange av Ridderne av den Magiske Kortstokk og satt bak lås og slå i et av fangehullene i slottskjelleren. Der blir de bevoktet av Ruter Knekt, som har nøkkelen til cellen hengende i beltet. Det vil si, de er fire bak gitteret, ettersom Caroline selvfølgelig ikke har villet skille seg fra sin kommende ektemann. Og nettopp Fredrik Frosk skal vise seg å bli deres redning. Etter lange og harde forhandlinger klarer Emmanuel og Fabel å overtale prinsessen til å fremskynde kjærlighetskysset. De gjør det på den måten at de, etter å ha forsikret seg om at Ruter Knekt sover tungt, løfter frosken ut mellom sprinklene, så kysser Caroline ham: - Æsj! og vips, så står en ung mann der, med 
pipekrave og gullkrone og lange lyse lokker. Prins Fredrik har åpenbart ikke fått med seg mye av det som skjedde $i$ hans liv som frosk og har mest lyst til å overlate dem til deres egen skjebne og komme seg ut av det stinkende kjellerhullet det forteste han kan. - Herregud, for en dust! Men de tre får til slutt forklart ham alvoret i situasjonen. Motvillig tar han på seg oppgaven med å lirke nøkkelen løs fra beltet til den fryktinngydende fangevokteren og låse opp celledøren, før han, til Emmanuels store tilfredsstillelse, tar bena fatt og forsvinner som et lyn ut av historien.

Emmanuel, Fabel og Caroline tar seg med list og lempe opp til kongens indre gemakker og får heseblesende fortalt sin historie til en søvndrukken og hoderystende monark. Ikke uventet har han vanskelig for å feste lit til inntrengernes beretning, dessuten er hans tillit til Madagaskar urokkelig, års tro tjeneste tatt $\mathrm{i}$ betraktning. Rådgiveren blir tilkalt, og kampen mot renkemakeren synes nok en gang å være tapt. Inntil den grønne puddelen kommer i skade for å nevne en detalj som bekrefter vennenes fremstilling av det siste døgnets hendelsesforløp. Madagaskar skjønner at maskespillet henger i en tynn tråd, og i et anfall av desperasjon påkaller han Ridderne av den Magiske Kortstokk, som styrter inn på kongens soverom og omringer de tre. Kongen forferdes av det han ser, og om han ennå lar tvilen komme rådgiveren til gode, slipper han å lure noe mer når Madagaskar beordrer Spar Ess til å gi ham en omgang med pisken. - Herregud! Etter mishandlingen utroper Madagaskar seg til konge og håner en blødende kong Sander for alle hans svakheter som regent. - Herregud! Idet fangene skal føres bort, ber den nye kongen, klok av skade etter den første rømningen, om å få overrakt Fabels ryggsekk. Han tar seg god tid til å gjennomsøke den. Og akkurat idet han står med ønskebilletten i hånden, eller poten rettere sagt, og undrer seg på hva det kan være for noe, går døren opp, og inn kommer kongens personlige tjener med frokostbrettet. Overrumplet av synet som møter ham, slipper han brettet i gulvet og roper i forskrekkelse: «Men! Madagaskar!» Og poff, så forsvinner puddelen i en grønn støvsky. - Herlig! I samme sekund oppheves makten han hadde over de fire ridderne. De kaster seg ned på gulvet og hyller Sander og hans redningsmenn. - Og kvinne! - Og kvinne. Ikke minst Spar Ess, som nesten ikke er til å trøste, og som trygler på sine knær om forlatelse for sine ugjerninger og som bedyrer på vegne av seg selv og sine kolleger at de fra denne dag av står fullt og helt i den ene og uovertrufne hersker av Tekirekkis tjeneste.

Dagen som så vidt er påbegynt blir en gledens dag, senere innstiftet som nasjonaldag nummer to i riket. Om kvelden er det stor fest på slottet, der Mirabella, etter å ha blitt løst fra søsterens forbannelse, underholder selskapet med harpespill, så vakkert og betagende at det overdøver Bellamiras klagerop fra fan- 
gehullet, helt inn i de sene nattetimer. Emmanuel og Caroline, selv om det er litt i tidligste laget, forlover seg, og Fabel får stillingen som hoffnarr. Alle er glade. En ny æra har begynt.

Eventyret slutter med at prinsen spør kongen: «Skal jeg være her hos deg nå?» «Ja,» svarer kongen.

«For alltid?»

«For alltid.»

«Passer du på meg, uansett hva som skjer?»

«Du har ingenting å frykte, min sønn,» svarer kongen. «Uansett hva som skjer, vil jeg være der og passe på deg. Uansett hvor din vei måtte føre deg, vil jeg være ved din side og beskytte deg. Gjennom natten og inn i dagen.»

$$
[\ldots]
$$

Min første tanke var at det hadde noe med Mona å gjøre. At Eva hadde funnet noe av det jeg hadde skrevet til henne, eller hun til meg, som jeg hadde glemt å kvitte meg med. «Eva, hva er det?» sa jeg, livredd for svaret. Og så åpnet hun munnen, men det kom ikke en lyd ut av henne, det var bare et tomt hull som åpnet seg, inn mot det som hadde vært min kone, men som ikke var det lenger, som bare var tomrommet hun hadde etterlatt seg da hun ble revet bort.

Jeg fikk se bilen. De forsøkte å nekte meg det, men jeg insisterte. Den sto inne i en verkstedhall, jeg husker ikke hvor, og lignet en skrøpelig gjenstand som en eller annen gigantisk skapning hadde klemt sammen med hendene og som først etterpå hadde blitt hard, massiv, kompakt, alt det som hadde vært muligheter og bevegelse lukket inne i en skrukkete kloss som ikke lot seg åpne, som ingen kraft i verden kunne bryte fra hverandre, slik at det som hadde vært inni den kunne komme seg ut og begynne å leve igjen.

Jeg fikk se Ole-Jakob. De forsøkte å nekte meg det også. Men til slutt slapp jeg inn $\mathrm{i}$ likkjelleren, der de etter mye om og men avduket noe som var så fjernt fra å ligne noe jeg hadde sett før at da jeg kastet opp, var det ikke fordi det var ham, men på grunn av det jeg hadde sett, ene og alene på grunn av det. 
Hun stanset ikke før hun kom helt bort til meg. Der stilte hun seg opp, så nær meg at jakkene våre berørte hverandre. Vi sto slik lenge, uten å si noe. Jeg kikket på henne i smug. En liten klump med smør eller majones satt fast i munnviken hennes. Det irriterte meg, at hun hadde spist. Og en trang kom over meg til å fortelle henne om Ole-Jakob, hvordan han så ut da han lå på den blå metallbenken. Beskrive for henne øynene hans, som hadde eksplodert i sammenstøtet. Beskrive hullet etter munnen som var borte. Som om et rasende monster hadde revet ham i fillebiter, hadde jeg lyst til å si, som om det grønne trollet hadde innhentet ham og slått ham i hjel og maltraktert ham med kjempestyrken sin.

«Hvordan går det med deg?» sa jeg.

Dette svarte hun ikke på, hun bare ble ved med å stirre utover det grønne havet på den andre siden.

Munnen min smakte fremdeles av spy.

En trailer kjørte forbi nede på veien.

«Det går bra,» sa hun og så ut som hun kunne segne om når som helst.

Da vi kom hjem om kvelden, virket huset nytt. Det var som vi akkurat hadde flyttet inn i det. Bildene på veggene så ut som de nettopp hadde fått bestemt plassen hvor de skulle henge, kjøkkenet like ryddig og strøkent som et utstillingseksemplar i en butikk, så dødt og pregløst, alt sammen, som om det ikke tilhørte noen ennå, det som var der.

\section{$[\ldots]$}

Jeg lette etter noe å si til Stine, som kunne hjelpe henne, noe alminnelig, noe fullstendig harmløst, noe som hadde et løfte i seg, som ville overbevise henne om at faren var over, at det var trygt for henne å begi seg videre. Jeg ønsket å si noe som kunne stake ut en ny kurs for henne, hun min lille engel, den ene jeg elsket over alt på jord. Men jeg kom ikke på noe. Og visste heller ikke hvor det førte hen, dette «videre». Dessuten virket det som hun ville være i fred. Hun lignet Ole-Jakob med sin innesluttethet. Og jeg så for meg at hun var sammen med ham, der inne et sted, at det var hennes forsøk på å forstå ham, at hun prøvde å få ut av ham et svar, at det var derfor hun ikke ville at vi skulle forstyrre henne. Forstyrre dem.

Da hun kom hjem etter å ha vært på skolen igjen for første gang, slengte hun fra seg sekken i gangen der jeg hadde sagt til henne tusen ganger at den 
aldri skulle ligge, sparket av seg støvlene midt på teppet og gjorde et forsøk på å henge opp boblejakken som mislyktes, slik at den ble liggende som en brannfarlig uformelighet over panelovnen under knaggene. Jeg ville si noe til henne, men da var hun allerede gått opp på rommet sitt, og i stedet for å rope henne tilbake, tok jeg jakken hennes og hengte den på plass, satte støvlene på skostativet, la sekken på benken under speilet og innså at jeg aldri mer ville komme til å irettesette henne for noe. Hun lever. Hun skal bare leve. Etter dette skal vi ikke kreve noe annet av henne enn at hun lever.

Blant dem vi kjente var det enten slik at de unngikk oss, så sant det var mulig, eller motsatt, at de knapt greide å holde seg borte fra oss, de var på døren tidlig og sent, og var de først kommet, ville de ikke dra, som om de hadde fått det for seg at vi ikke ville overleve med mindre de var der og holdt oss oppe. De følte seg kanskje forpliktet til det. Hvis det ikke var fordi de opplevde at de tok del i noe stort, og derigjennom fikk tildelt en viktig rolle, at de med sin deltagelse og oppofrende innsats ble skrevet inn i den historien som siden skulle berettes om familien Meyers gjennomlevelse av katastrofen. Det var sikkert urettferdig fra min side, men jeg kunne ikke la være å se dem for meg der de løp ut i verden igjen etter å ha vært hos oss og fortalte siste nytt fra sorgens hus. Og jeg så for meg hvordan de vokste på det mens de brettet ut detaljene til alle dem som ikke våget å ta kontakt, som begrenset sin medfølelse til noen tekstmeldinger i ny og ne, så ynkelige at jeg sjelden orket å lese dem ferdig. Ikke at de var noe bedre, de meldingene vi fikk ansikt til ansikt. Det var nesten ikke til å fatte, hvor mye de hadde på hjertet, enkelte av dem, livsvisdommer og oppmuntrende ord vi ville fått bedre formulert om vi hadde slått opp i et ukeblad. Du skal se dere kommer styrket ut av det, hørte jeg en si til Eva. Hadde jeg hatt krefter til det skulle jeg tatt øksen som fremdeles sto plantet i tv-en, hugget av henne armen og gitt den til henne og sagt: Du skal se du kommer styrket ut av det.

Og jeg tenkte på om jeg gjorde det samme som Stine gjorde, isolerte meg, som en måte å få kontakt med Ole-Jakob på. Oppholde meg i hans verden. Være der helt til jeg forsto ønsket om å bli knust.

Tiden gikk. Jeg så hvordan Eva reiste seg igjen. Sorgen gjorde henne sterk. Kanskje de hadde rett allikevel, de som var innom og oppmuntret henne? Hun stålsatte seg og nøt beundringen hun fikk for sin ranke holdning. Bevegelsene hennes var dessuten blitt raskere, la jeg merke til, på kjøkkenet, $\mathrm{i}$ hagen, $\mathrm{i}$ butikken, overalt, alle gjøremål ble unnagjort i en fei, det ene etter det andre, som om alt hun fikk utrettet var brikker i et puslespill hun holdt på med, et puslespill der motivet var livet vårt, slik det hadde vært før. «Hun er effektiviteten selv!» hørte jeg noen si, det kunne ikke sies bedre. Alt utført med hard hånd, liksom det som 
en gang begrunnet handlingene hennes var gått tapt og det eneste som gjensto var å gjøre dem allikevel. Alt, bortsett fra å kjøre bil, som hun nektet, det ene som satt fast $\mathrm{i}$ henne, som hun ikke greide å gjøre noe med. Jeg kjente henne nesten ikke igjen. Hun var seg selv lik, men forandret til det ugjenkjennelige, en slags maskin som var satt til oppgaven med å holde det ut, uten å vite hvorfor. Hun arbeidet. Det var dét hun gjorde. Et kjærlighetsløst stykke livsarbeid som skulle vare tiden ut. Jeg hadde tatt fra henne det hun hadde av kjærlighet. Først jeg, så Ole-Jakob, de to mennene i hennes liv.

Jeg forsøkte å følge hennes eksempel, jeg friskmeldte meg og ga Lise beskjed om å sette opp pasienter så langt utover ettermiddagene og kveldene det måtte være behov for, unnet meg knapt pauser, hilste svimmelheten velkommen, gjorde hva jeg kunne for å bli utmattet, nedkjørt, overarbeidet, så skjelven enkelte ganger mot slutten av de altfor lange dagene at jeg ville risikert å miste autorisasjonen om det hadde kommet de rette instanser for øre.

\section{$[\ldots]$}

Zagreb stirret på meg en lang stund. Så smilte han.

«Det sies at mannen som bygde det, til seg og familien, at han fant ut at kona hadde bedratt ham, det var da han akkurat hadde begynt på grunnarbeidet, og at han ble gal og drepte både henne og de to barna deres. Etterpå støpte han likene deres inn i kjellergulvet. Allikevel gjorde han huset ferdig, med to leiligheter vegg i vegg, og flyttet inn i den ene av dem. Og så må det ha klikket for ham for andre gang, for han laget seg en snedig innretning, et lite bur til å ha på brystet, med vegger og tak, men uten gulv. Inni buret plasserte han en utsultet rotte, og så festet han det til brystkassen på en slik måte at det ble umulig for ham å få det av igjen. Og så må han rett og slett ha gitt seg til å vente. Da de fant ham, satt han med munnen på vidt gap. Han hadde vel prøvd å hjelpe rotta ut den veien. Sporene tydet på at han hadde vært overalt i huset før han døde, det var blodsøl i alle rom. Rotta fant de oppe i halsen på ham. Den hadde gnagd seg et godt stykke oppover, men hadde fått hodet i klem mellom ganen og nakkevirvelen og blitt sittende fast og ikke greid å komme seg videre.»

Zagreb flirte.

«Litt av en skjebne! Sulte ihjel midt inni nitti kilo ferskt kjøtt!»

Han strøk begge hendene gjennom håret. 
«Men det høres mest ut som en dårlig skrekkfilm, spør du meg,» sa han og gjespet, som om samtalen plutselig kjedet ham. «Eller det rommet Orwell skriver om. Hva det nå var.»

«Hva er din teori, da?» spurte jeg.

Men da satt han med en liten datamaskin eller mobiltelefon $\mathrm{i}$ hånden, som la beslag på all hans oppmerksomhet. 


\title{
Maldita porra do inferno
}

\author{
Stig Saterbakken \\ Tradução do norueguês: \\ Guilherme da Silva Braga
}

A tristeza chega de muitas formas. É como uma luz que se apaga e reacende. Fica lá, e parece insuportável, e então some, porque é insuportável, porque não é possível tê-la por lá o tempo inteiro. As pessoas se enchem e se esvaziam. Mil vezes por dia eu me esquecia que Ole-Jakob estava morto. Mil vezes por dia eu me lembrava de repente. As duas situações eram insuportáveis. Esquecê-lo era a pior coisa que podia acontecer. Lembrá-lo era a pior coisa que podia acontecer. O frio chegava e saía. Mas nunca o calor. Havia somente o frio e a ausência do frio. Como ficar de costas para o mar. Tornozelos gelados toda vez que uma onda quebrava. Depois aquilo ia embora. Depois voltava.

Enquanto eu estava assim, o sol havia se posto e a noite havia caído, e desde então houve apenas noite.

Nos dias após o enterro eu não fiz grande coisa a não ser assistir à TV. Como se tivesse a esperança de que, se eu permanecesse sentado daquele jeito, sem me mexer, total e absolutamente concentrado naquilo que acontecia na tela, a dor aos poucos desapareceria, e então eu passaria a fazer parte daquela outra realidade em que a dor não existe. Houve uma tarde em que assisti a um filme da Pantera Cor-de-Rosa. Era aquele em que Clouseau (Peter Sellers), durante o interrogatório na casa de uma família inglesa abastada, prende a mão na manopla de uma velha armadura e transforma a sala em um campo de batalha antes de terminar o resumo à moda Poirot. E de repente não pude conter o riso. Eu, que tinha a certeza de que nunca mais daria uma risada na vida, ri como se um bicho dentro de mim tentasse sair me comendo de dentro para fora. Por fim tive que desligar a TV; se houvesse assistido ao filme até o fim, eu teria explodido.

"Essa maldita TV do inferno!" Certa noite eu estava fumando na rua durante o intervalo entre dois seriados que eu tinha começado a acompanhar e vi no pátio a sombra de Eva, que deslizou como um espectro. Depois ouvi uns barulhos vindos da garagem, mas não pensei grande coisa a respeito. Quando 
voltei à sala a TV estava quebrada, com o cabo do machado para fora da tela, que parecia mais uma massa preta e viscosa do que vidro estilhaçado. Ela estava no meio da peça, bufando, como se tivesse dificuldade para respirar. Por sorte - ou por azar - Stine estava lá; ela envolveu os joelhos com os braços e começou a chorar, e de minha parte a única coisa que importava era fazer o possível para acalmá-la. Enquanto eu a abraçava, pensei em como ao longo dos anos uma das minhas queixas recorrentes tinha sido a quantidade de horas que Eva passava em frente à TV, em como aquilo tinha me dado nos nervos inúmeras vezes, na apatia que aquilo simbolizava, no passatempo sempiterno, defendido por ela como um relaxamento, necessário à manutenção da vida, se eu a entendia bem, à espera da próxima batalha, como se o trabalho dela fosse a única realidade e o restante do tempo não servisse para nada além de recuperar as forças para estar em condições de retomá-lo, como se ela tivesse desistido de ser a pessoa que na verdade era quando estava comigo em casa, quando estava conosco em casa; era uma coisa que guardava para os dias de trabalho, como se já não fosse necessário fazer nenhum esforço, porque o trabalho comigo estava terminado, ao contrário do que acontecia com o trabalho relativo às outras pessoas: tudo isso aflorava em mim simplesmente ao vê-la meio deitada no sofá com o rosto banhado pela cintilação devoradora na tela da TV.

Depois que a TV foi quebrada, longas caminhadas ocuparam o lugar de CSI Miami, Dexter e os antigos clássicos do TCM. Eu preferia fazer rotas por onde nunca tinha andado, e cheguei a descobrir caminhos que eu não conhecia. Uns me davam a impressão de não serem usados desde muitos anos, porque os galhos obstruíam a passagem e roçavam minha jaqueta quando eu passava. Às vezes, quando já estava escuro, eu descobria uma luz, várias luzes, minúsculas em função da distância, mas assim mesmo visíveis através de uma interminável fileira de aberturas em meio à folhagem. O pisca-pisca de um carro, por exemplo, podia surgir bem à minha frente logo depois que um semáforo houvesse trocado do amarelo para o verde, bem ao longe.

Ao voltar para casa eu sempre parava um tempo no corredor e escutava antes de entrar para ver se alguém estava chorando.

Era muita coisa que eu não entendia. A brutalidade em tudo: no mercado, a forma como as pessoas empurravam os carrinhos à frente, a forma como remexiam nos produtos congelados, ou como postavam-se junto às gôndolas de verduras e falavam em voz alta, como se nada tivesse acontecido. Na rua, o tráfego infernal, os motoristas fincavam o pé no acelerador e enfiavam a mão na buzina assim que alguém da fila demorasse um pouco mais para dar a partida ao abrir do sinal. Os 
estudantes que vinham em grandes bandos e que davam a impressão de estarem prestes a explodir de felicidade. Barulho por toda parte, carros em movimento, pessoas falando, música alta. Tudo para abafar o imenso abismo de silêncio que teria se aberto se todos parassem com aquilo que estavam fazendo. Pessoas que falavam, mas nenhuma delas sobre Ole-Jakob. Malditos filhos da puta do inferno. Como era possível? Sobre o que podiam estar falando, quando ele estava morto?

O mundo zombava de nós. Zombava de Stine, que devia fazer parte daquela multidão vibrante, que devia ser uma peça naquele grande jogo ainda durante muitos anos, um jogo que mal havia começado quando ela foi excluída. Por mais que eu soubesse que ela voltaria a ele mais tarde. E que tudo muito provavelmente daria certo, com o passar do tempo. "Com o passar do tempo": uma zombaria, também isso. A ideia de que tudo acabaria bem. De que ela conseguiria. De que em não muito tempo dançaria valsa, daria sorrisos e risadas, faria brincadeiras e falaria bobagens, total e completamente dedicada à eterna baboseira de que era composta a vida em meio a outras meninas de sua idade, como devia compor-se, uma extensão necessária no caminho rumo à identidade adulta. Ela voltaria a tudo isso com a coragem renovada; era apenas uma questão de tempo. Aquilo que pesava sobre ela seria posto de lado, não de todo, mas o suficiente para que conseguisse levar a vida em meio às outras pessoas, o suficiente para que mais uma vez pudesse dançar a valsa.

Durante os primeiros dias ela não disse nada. O que havia a dizer? Toda vez que eu ou Eva, em nosso temor por saber como estava, tentávamos extrair qualquer coisa dela, ela fechava o rosto, duro como uma pedra, ou então começava a chorar, o que por fim nos deixou com um temor de tentar que era maior do que aquilo que poderíamos descobrir se conseguíssemos. Quando por fim ela quebrou o silêncio, foi com xingamentos e palavrões. MALDITA PORRA DO INFERNO, foi a primeira coisa que a ouvi dizer. Foi como ouvir Eva, a voz era igual. O agente funerário tinha estado em nossa casa para discutir os últimos detalhes, eu tinha acabado de fechar a porta quando ouvi Stine na cozinha. MALDITA PORRA DO INFERNO! Senti uma pontada de alegria. O primeiro sinal de vida de uma pessoa que parecia ter nos deixado! Fui ao encontro delas. Stine havia se levantado, aquilo se derramava para fora dela, como se estivesse vomitando, uma grosseria pior do que a outra, as acusações choviam. Eva estendeu o braço e mal conseguiu segurá-la antes que a mão fosse empurrada de volta. Olhei para as duas e notei como estavam parecidas, mãe e filha. Stine era mais bem-talhada, como se houvesse pegado o rosto de Eva e o aperfeiçoado. E pensei em quantas vezes, ainda pequena, ela se havia sentado em silêncio e escutado o irmão falar sobre tudo o que existe no céu e na terra, na maneira como sentava-se para observá-lo e admirá-lo, como 
deixava todo o falatório para ele, como o mandava à frente no mundo para que ele pudesse voltar e lhe dizer como era.

O tempo inteiro eu tentava pensar em outra coisa, mas não conseguia, a concentração me escapava, meus pensamentos eram como desenhos malfeitos, que tinham de ser rasgados de imediato.

Eva só começou a chorar semanas mais tarde. Mas um dia eu voltei de um daqueles malditos passeios do inferno meus e ouvi o aspirador de pó na sala, encontrei-a atirada no chão, soluçando, como se tivesse chorado tanto quanto podia e não tivesse mais nada a oferecer, mas assim mesmo não conseguisse parar. Levantei-a, ela era pesada como um homem forte e segurava o aspirador de pó com tanta força que precisei afrouxar dedo por dedo antes de conseguir soltá-lo. Eu a coloquei no sofá e apoiei a cabeça dela no meu colo. Grandes manchas úmidas eram visíveis no chão onde momentos antes ela estava caída. Passei a mão nos cabelos dela e tentei acalmá-la. "Já passou, já passou”, eu disse, como se falasse com uma criança. "Nós vamos sair dessa. Nós vamos sair dessa." Mas assim que falei eu percebi o vazio daquelas palavras, o vazio naquilo que eu tinha acabado de dizer, naquilo que eu tinha me convencido a querer mais uma vez - exatamente como quando eu voltava depois da "minha aventura" -, o vazio em tudo que tinha existido, em tudo que existia e em tudo que haveria de existir. E eu sabia que, independentemente do que eu dissesse, independentemente do que eu pudesse levá-la a crer, mais cedo ou mais tarde aquilo tudo seria revelado como um juramento vazio, como uma promessa sem qualquer tipo de garantia, sem qualquer ligação com a realidade que logo voltaria para nos destruir. Eva continuou deitada, imóvel. Senti o corpo dela tenso enquanto eu a abraçava e o aspirador de pó continuava a rugir para as paredes. O que vamos fazer?, pensei. Quando tudo isso acabar? Quando deixarmos a tristeza para trás? Quando superarmos isso tudo, se é que vamos superar, que diabos nós vamos fazer?

Eva tinha entrado lá para arrumar, eu sabia, mesmo que eu não aguentasse entrar, não sei ao certo por quê. Por medo de que ele estivesse lá, em meio às coisas dele? No fim aquilo pesou tanto para mim que tive a impressão de que eu não conseguiria fazer mais nada enquanto não entrasse. Esperei um dia em que eu estivesse sozinho em casa. E mesmo assim passei um longo tempo parado em frente à porta. Lá me ocorreu que fazia muito tempo desde a última vez que eu havia entrado no quarto dele, eu não tinha entrado nenhuma vez desde a minha volta para casa, nenhuma vez desde que eu os tinha abandonado para viver com Mona. Primeiro eu bati. Depois abri a porta e entrei.

Eva não tinha arrumado. Tudo estava conforme ele havia deixado: pilhas de roupas no chão, fone de ouvidos e toalhas e CDs e revistas e latas vazias de 
bebida energética, fios, um desodorante, uma lata de spray, o videogame como um pequeno rochedo em meio a um redemoinho de bagunça. A porta do armário estava aberta, e de lá saía uma cesta com roupas de baixo. No parapeito da janela havia uma fileira de esqueletos uniformizados, pintados a mão de forma elaborada, com um suporte quadrado sob os pés de cada um. Me ocorreu que aquela era a única coisa marcada pela ordem. O cabo do videogame tinha uma parte desencapada bem próxima ao plugue, e quando me abaixei para tirá-lo da tomada essa parte soltou fáscas e revelou o cobre que havia lá dentro. Assustado como uma criança, deixei aquilo de lado.

Me sentei na cama. O edredom parecia úmido, e uma das pontas estava desbotada. Olhei para o teto. Todas as fotografias e pôsteres que eu vira em outras épocas tinha desaparecido. Mas havia uma frase escrita com pincel atômico, em letras de forma grossas: NÃO QUERO ACORDAR AMANHÃ. Na pantalha do abajur estava colado um adesivo que havia começado a derreter; a parte de cima havia se enrolado em um pequeno tubo. Levantei o edredom. Embaixo havia uma embalagem de chocolate e uma meia. Peguei a meia na mão. Era uma meia branca com uma listra azul na parte de cima. A sola estava preta de sujeira, e havia folhas de grama ainda pressas ao material fino. Me perguntei quantas vezes eu teria pedido a ele e a Stine que não saíssem ao pátio usando nada além de meias. E pensei naquilo que eu havia dito tantas vezes, en já disse isso mil vezes, que eles adoravam usar para me confrontar. Mas naquela ocasião precisa a razão estava do meu lado. Levei a meia ao nariz. O odor de chulé fez com que tudo girasse ao meu redor. Fiquei sentado, cheirando. Apertei a meia contra o rosto e fiquei respirando através das fibras. Era como se eu estivesse sendo levado pelo repuxo, como se eu me afogasse na bagunça dele. Era um sentimento maravilhoso.

Um dia eu peguei um ônibus, fui até o centro da cidade e voltei. Cochilei por uns instantes, e quando acordei eu não sabia onde estava. Fiquei sentado com a testa apoiada no vidro, que vibrava de leve com o ruído do motor, e tentei me concentrar naquilo que eu via, fixando os olhos nas construções e nos veículos da paisagem, que desfilavam à minha frente e criavam histórias sobre as pessoas a quem pertenciam. A certa altura o ônibus fez uma curva e passou por um caminhão que transportava cascalho na caçamba. Na parte mais alta da encosta havia um moraina com raízes de plantas espalhadas para todos os lados. Um blusão branco pendurado para secar em cima de um lençol branco parecia um rosto velho com olhos cansados e uma boca torta. Também vi muitas cercas e estufas, uma em estado pior do que a outra, como se tivessem sido erguidas com o objetivo de tornarem-se decrépitas. Mas quando tornamos a nos aproximar dos grandes loteamentos, foi como se tudo se tornasse mais solene, até mesmo a natureza, 
como se tudo, as pessoas, os bichos, as plantas, desde lá até o centro da cidade estivessem a mostrar-se com um aspecto mais favorável. Um casal jovem havia sentado à minha frente; a garota pousou a cabeça no ombro do rapaz, que de vez em quando inclinava a cabeça para a frente e olhava para ela. Notei que senti uma inveja enorme dele, de ambos. Um sentimento de paz abençoada pairava sobre os dois, que se encontravam despreocupadamente inseridos num ambiente que ainda não tinha forças para abalar a felicidade e a paixão que sentiam. Para esses dois, pensei, o mundo não teria nada a dizer. Nada é capaz de perturbá-los. Estão em perfeito equilíbrio. $\mathrm{O}$ amor e o desejo igualmente divididos, sem nenhum questionamento acerca de qual dos dois seria o mais desejoso. Quando eu estava saindo, me virei em direção a eles e disse: “Lembrem-se desse momento!". O rapaz levou um susto, olhou realmente apavorado para mim, e quando o ônibus seguiu viagem eu tive um relance do casal na janela, ambos me olhavam como se eu fosse uma pessoa que houvesse tentado fazer qualquer coisa, sem que entendessem o quê.

Acho que foi na mesma tarde em que Boris me falou sobre a casa misteriosa, num lugar qualquer da Eslováquia, ele não sabia onde, que funcionava de maneira que as pessoas que tivessem os contatos certos e pagassem um determinado valor, sem dúvida altíssimo, recebiam uma chave e um papel com um endereço, e também um horário, um horário exato em uma data predefinida, e se as pessoas entrassem na casa precisamente naquele instante, haveriam de se confrontar com os piores medos que têm na vida. E, segundo Boris, houve pessoas que afirmaram ter entrado na casa e saído com a consciência leve, curadas de tudo aquilo que lhes parecia um fardo, alegres e contentes, sem nenhum resquício de angústia no corpo. Tinham visto as piores coisas imagináveis, e depois daquilo nada mais poderia ameaçá-las. Outras, segundo me disse, tinham saído com o semblante terrível e desfigurado, a tal ponto que até mesmo pessoas muito próximas tiveram dificuldades em reconhecê-las. Um homem tinha saído com a pele totalmente cinza e o nariz deslocado para a bochecha e, sem jamais dizer sequer uma palavra a qualquer outra pessoa, trancou-se em um cômodo no apartamento onde morava e lá ficou até morrer semanas mais tarde. Outro teria saído da casa para ir direto a uma linha férrea e jogar-se embaixo de um trem de carga que o decapitou. Houve os que ficassem cinco minutos na casa e saíssem absolutamente convencidos de que tinham passado anos trancados lá dentro. Houve os que acreditaram não ter percebido diferença nenhuma até muito tempo depois, quando o que havia de completamente aterrador nos pensamentos surgidos lá dentro revelou-se de repente. E houve os que dissessem que o importante era manter-se acordado lá dentro, que era possível lidar com aquilo, com a casa, desde que não se dormisse lá dentro, porque uma vez que se adormecesse não havia mais volta, tudo estava perdido. 
Primeiro achei que era invenção dele, uma criação desesperada que pudesse me fazer pensar em outra coisa, uma vez que certamente me considerava indiferente às formas tradicionais de consolo. Ao recebê-lo em casa, eu percebia que ele procurava incessantemente dizer coisas que mesmo por uns poucos minutos pudessem tirar meus pensamentos da única coisa que me ocupava, que ele sinceramente desejava, por um instante que fosse, substituir aquilo por outra coisa, qualquer outra coisa que não tivesse o nome Ole-Jakob.

Ele parecia entusiasmado, tagarelava sem parar, descrevia todos os detalhes. O homem que eu devia contatar chamava-se Zagreb. Para encontrá-lo, segundo Boris, era preciso ir a um bar chamado Neusobl em Bratislava, no bairro atrás da Reduta, a casa de concerto da orquestra filarmônica, e dizer ao bartender, depois de ter pedido uma Corgoň, que gostaria de ver o lugar onde "a esperança transforma-se em merda". Parecia a trama de um romance de Boris Snopko. E no fundo eu achava mesmo que era.

Durante o resto da tarde ele fabulou sobre o que provavelmente teria encontrado caso se aventurasse a entrar na "casa do medo". Em circunstâncias normais começaríamos a fazer uma série de provocações. Mas naquele instante ele não precisava me perguntar. Talvez sentisse uma vontade enorme de perguntar. Mas, como a resposta já estava dada, não seria nenhum horror deixar o assunto de lado.

Eu me senti grato por isso. Não naquela hora, porém mais tarde. Todas as histórias que ele contou. Eu não prestava atenção, porque era indiferente àquilo tudo, ele tinha razão, mas assim mesmo eu ouvi, como se uma parte de mim estivesse prestando atenção para fazer uso daquilo mais tarde. Lá, na hora, ele me irritou a ponto de eu ter que me segurar para não o mandar embora. Chegar entusiasmado daquele jeito, querendo tirar minha tristeza de mim! Foi como se ele me interrompesse durante um culto religioso. Aquela disposição era uma ofensa, aquelas palavras de apoio eram blasfêmias. Mas uma parte ínfima de mim reconheceu aquele esforço e o amou por aquilo, por ter persistido, mesmo sabendo o tempo inteiro que nada chegava ao meu âmago, por ter ao mesmo tempo deixado que eu permanecesse sob o poder da minha indiferença e feito tudo o que podia para me libertar, por ter simultaneamente me deixado e não me deixado em paz.

Depois pensei naquilo: para ele, deve ter sido como visitar um amigo na prisão.

Meu exemplar da tradução norueguesa de um dos livros dele tinha uma dobra no canto da página trinta e pouco. A história era sobre uma sociedade em que, por conta da superpopulação, havia introduzido uma lei que permitia a todos os cidadãos maiores de idade o direito de matar uma pessoa sem responder 
a qualquer tipo de processo criminal. Mais tarde, quando passou a escrever em norueguês, ele procurou em vão por uma editora disposta a publicar o livro. Também não conseguiu lançar traduções do material já publicado. E quando, numa tentativa derradeira, traduziu um dos manuscritos em norueguês para eslovaco, a antiga editora dele tampouco se interessou. Eu não sabia se ele tinha escrito outros livros depois disso, e minha impressão era que toda aquela imaginação fértil desde então era usada para criar as mais variadas explicações para essas recusas. Além disso, ele investia uma quantidade enorme de recursos em falar mal de tudo que era publicado, estivesse ou não relacionado a seus livros. E, mesmo que houvesse uma certa dose de humor nisso tudo, ele acusava outros autores de ter surrupiado ideias suas, por mais distantes que pudessem estar do tipo de coisa que podia ter inventado. Tornou-se uma obsessão para ele. Como ninguém gostava do que ele escrevia, ele não gostava de ninguém que escrevia. Tudo isso com tanta intensidade que provavelmente não lhe restava energia para investir naquilo que, se tivesse visto a luz do dia - essa era uma premissa tácita de todas as sentenças implacáveis que ele prolatava -, teria superado todo o resto.

Quando Ole-Jakob era pequeno contei-lhe uma fábula inventada à medida que eu a contava, um capítulo por noite, mais tarde colocada no papel, já que ele não parava de tagarelar a respeito do assunto, e mandada para uma editora, porque a minha irmã, que ficara sabendo de tudo, achou que não faria mal nenhum, e que após receber pequenos ajustes foi publicada com o título O príncipe que não sabia, dedicado à pessoa que tinha me levado a escrever o livro e que, segundo eu imaginava, um dia haveria de ler a história em voz alta para os filhos e mostrar-lhes a dedicatória, cheio de orgulho. A fábula contava a história do príncipe Emmanuel no reino de Tekirekki, um príncipe que não sabe que é príncipe, porque o pai dele, o rei Sander, que é viúvo, tirou-o de casa quando ainda era pequeno para que tivesse uma infância comum com uma família comum, frequentasse uma escola comum, tivesse amigos comuns, em suma, para que não recebesse nenhum tipo de tratamento especial nem fosse tratado a pão de ló até que estivesse maduro o bastante para conhecer a incrível linhagem a que pertencia. - Meu Deus, que rei burro! - disse Ole-Jakob, desesperado ao pensar em tudo que esse menino havia de perder. Nesse meio-tempo fica claro que Bellamira, a mãe da família adotiva, é uma bruxa que não pode ter filhos e se toma de amores pelo menino a ponto de querê-lo para si, o que a leva a lançar sobre o rei uma maldição que o faz esquecer que tem um filho. E assim os dois, pai e filho, vivem por muitos anos, sem nada saber a respeito um do outro. Sozinho no castelo, o rei aceita o pedido feito por um familiar distante, rei de um país assolado por uma guerra civil, que pergunta se a filha, a princesa Caroline, poderia morar com ele até o fim da guerra. Mas 
acontece que o rei Sander recebe e educa Caroline como se fosse sua própria filha, e os habitantes de Tekirekki, mesmo sabendo que isso não é verdade, começam a pensar nela como sendo a filha do rei e a legítima herdeira do trono. Os habitantes também manifestam grande interesse pelo bicho de estimação da princesa, o sapo Fredrik. Corriam boatos de que seria um príncipe enfeitiçado, que a princesa, no que dia em que se tornasse maior de idade, haveria de beijar para então casar-se com ele. Dito de outra forma, era o futuro rei que o povo via naquela criatura pegajosa com uma correia de ouro e uma coleira de diamantes que sempre chegava saltitando dois passos atrás da graciosa Caroline.

Bellamira, a mãe adotiva de Emmanuel, tem uma irmã gêmea, Mirabella, que também é bruxa, mas uma bruxa do bem. Mirabella é a única que conhece o plano maléfico de Bellamira, porque tem uma bola de cristal onde pode ler o pensamento de qualquer pessoa. Mesmo assim, não pode fazer nada para impedi-lo, porque Bellamira também lançou uma maldição contra a irmã que a impede de sair da casa onde mora. Assim, Mirabella decide atrair Emmanuel até sua casa e revelar-lhe toda a verdade. Ela faz isso tocando uma harpa mágica (na verdade os próprios cabelos, que alcançam o chão quando ela inclina a cabeça para o lado e que ela prende com a ponta do pé). A magia funciona: Emmanuel desperta e deixa-se levar por aquelas notas maravilhosa até a casa da bruxa, que por fora parece uma casa normal, mas por dentro tem as paredes e o teto feitos de alcaçuz. Ao mesmo tempo, Mirabella lança uma maldição sobre a casa dos pais adotivos, para que o tempo pare lá dentro até que a maldição seja desfeita. Mirabella conta a Emmanuel quem ele é na verdade e mostra-lhe o castelo, o pai e todas as outras pessoas que lá moram na bola de cristal. Ao ver a linda menina que anda pelos salões com um sapo na coleira o príncipe se apaixona de imediato, o que no entanto tem o cuidado de não revelar para sua aliada.

Mas há muitos perigos no caminho que leva à reunião da família. No castelo também mora o conselheiro do rei, um poodle verde chamado Madagascar - na verdade um porco cor-de-rosa transformado em poodle, porque Ole-Jakob achava os porcos nojentos - que um feiticeiro de Madagascar fez com que andasse sobre duas patas e aprendesse o uso da língua, e que naquele momento, após muitos anos a serviço do rei, havia tomado gosto pelo poder e começado a fazer planos para derrubá-lo e transformar Tekirekki em uma ditadura. Para concretizar o golpe de estado, ele conta com a ajuda de quatro armas secretas, mais precisamente, quatro super-heróis que podem ser conjurados por meio de um baralho mágico roubado do feiticeiro que o transformou.

Em outras palavras, não são poucos os desafios que esperam o príncipe que não sabia: primeiro ele precisa entrar no castelo vigiado, fazer contato com 
o pai e convencê-lo de que existe um laço de sangue entre os dois, para então revelar e impedir os planos maléficos do conselheiro. Sendo assim, precisa de um amigo e de um escudeiro para essa jornada cheia de perigos. Mirabella de bom grado teria feito companhia se pudesse. Mas ela teria de se contentar em orquestrar tudo da prisão domiciliar na casa de alcaçuz. - Como ela arranja comida, se não pode sair nunca? - Como você acha? No recanto mais a oeste do parque da cidade, sob a raiz de um velho carvalho, vive um anão corcunda chamado Fábulo, que não é particularmente corajoso, mas que ganha asas nas costas toda vez que sente medo. Fábulo é o melhor amigo de Mirabella e está a par de todos os perigos que ameaçam o reinado. O primeiro capítulo termina quando Emmanuel recebe de Mirabella instruções sobre como entrar em contato com Fábulo, e então é posto a caminho com as seguintes palavras: «O medo dá asas. Mas é quando aterrissamos que o trabalho de verdade começa!».

Emmanuel procura Fábulo na gruta secreta debaixo do carvalho. Os dois traçam um plano de ataque e começam a jornada rumo ao castelo, equipados com um pequeno arsenal que inclui o chamado bilhete dos desejos, que funciona de maneira que, se uma pessoa o tiver na mão e alguém disser o nome de um lugar qualquer no mundo, a pessoa desaparece rumo a esse lugar para nunca mais voltar de lá. Enquanto isso a missão revela-se mais dramática do que tinha se imaginado antes, uma vez que Madagascar se adianta em relação ao rei e envia cavaleiros de sua confiança ao encontro dos invasores do castelo: o Valete de Ouro, armado com uma lança, a Dama de Copas, sedutora irresistível, o Rei de Paus, armado com uma alabarda, e o Ás de Espada, um mestre no manejo do chicote. - Legal! Os encontros são violentos, e mais de uma vez Emmanuel é salvo por um Fábulo apavorado, que o agarra pela gola do casaco e o leva voando para um lugar seguro. Caroline é a única para quem conseguem revelar o complô, mas logo os três são capturados pelos Cavaleiros do Baralho Mágico e trancados a sete chaves em um dos fossos de prisioneiros na masmorra do castelo. Lá, são vigiados pelo Valete de Ouro, que tem a chave da cela pendurada no cinto. Ou seja, estão em quatro atrás das grades, uma vez que Caroline naturalmente não quis separar-se do futuro esposo. E quem os salva é justamente o Sapo Fredrik. Ao fim de uma longa e difícil negociação, Emmanuel e Fábulo convencem a princesa a antecipar o seu beijo de amor. Após todos se convencerem de que o Valete de Ouro está dormindo, o sapo é colocado para o lado de fora, por entre as barras da cela, e então Caroline o beija: - Argh! e pluft, lá está um rapaz com rufo, coroa de ouro e longos cachos dourados. O príncipe Fredrik claramente não se lembra de muita coisa acontecida durante a vida como sapo e pretende abandonar todos ao próprio destino e sair daquela masmorra fedorenta o quanto antes. - Мeu Deus, que burro! Mas os três 
por fim conseguem explicar-lhe a gravidade da situação. Embora contrariado, ele assume a tarefa de soltar a chave presa ao cinto do temível guarda e abrir a porta da cela, e então - para a grande satisfação de Emmanuel - dá no pé e some da história como um raio.

Com manhas e artimanhas, Emmanuel, Fábulo e Caroline chegam aos aposentos do rei e esbaforidos contam toda a história para um monarca zonzo de sono e um tanto incrédulo. Como se poderia esperar, o rei desconfia da história contada pelos invasores, pois tem uma confiança inabalável em Madagascar, que lhe serviu fielmente por anos a fio. O conselheiro é chamado e a batalha contra o conspirador parece novamente estar perdida. Até que o poodle verde dá com a língua nos dentes e menciona um detalhe que confirma a versão dos amigos em relação aos acontecimentos do último dia. Madagascar percebe que a farsa está por um fio e, tomado pelo desespero, invoca os Cavaleiros do Baralho Mágico, que invadem os aposentos do rei e cercam os três. O rei se apavora com o que vê, e mesmo que ainda estivesse disposto a conceder o benefício da dúvida em favor do conselheiro, essa dúvida some assim que Madagascar ordena ao Ás de Espada que o fustigue com o chicote. - Meu Deus! Ao fim da agressão, Madagascar proclamase rei e zomba do ensanguentado rei Sander e de todas as suas fraquezas como regente. - Meu Deus! No momento em que os prisioneiros estão sendo levados, o novo rei, já escaldado pela primeira fuga, pede que lhe entreguem a mochila de Fábulo. Ele passa um bom tempo a revistá-la. E, no momento exato em que tem a mão, ou melhor, a pata no bilhete dos desejos e se pergunta o que poderia ser aquilo, a porta se abre e o criado pessoal do rei entra com a bandeja do café da manhã. Surpreso ao deparar-se com a cena que encontra, ele deixa a bandeja cair no chão e grita assustado: «Ora essa! Madagascar!». E pluft, assim o poodle some em uma nuvem de pó verde. - Que demais! No mesmo instante o poder que tinha sobre os quatro cavaleiros desaparece. Os quatro prostram-se no chão e reverenciam Sander e os heróis. - E a heroína! - E a heroína. Até mesmo o Ás de Espada, que parece inconsolável e se põe de joelhos a implorar perdão pela crueldade, e que jura, por si mesmo e por todos os colegas, que daquele dia em diante encontra-se total e completamente a serviço do único e soberano rei de Tekirekki.

$\mathrm{O}$ dia que mal começou torna-se um dia alegre, mais tarde declarado o segundo dia nacional do reino. À noite há uma grande festa no castelo, durante a qual Mirabella, já libertada da maldição da irmã, entretém a companhia tocando harpa com tanta beleza e tanta emoção que a música chega a abafar os lamentos de Bellamira, que vêm da masmorra, até tarde da noite. Emmanuel e Caroline, um pouco às pressas, tornam-se noivos, e Fábulo torna-se bobo da corte. Todos estão felizes. É o começo de uma nova era. 
A fábula termina quando o príncipe pergunta ao rei: «E agora eu vou morar aqui no seu castelo?».

«Vai», responde o rei.

«Para sempre?»

«Para sempre.»

«E você vai cuidar de mim, não importa o que aconteça?»

«Você não tem nada a temer, filho», responde o rei. «Não importa o que aconteça, eu vou estar aqui e cuidar de você. Não importa aonde a vida o leve, eu vou estar ao seu lado e vou protegê-lo. Através da noite e rumo ao dia.»

\section{$[\ldots]$}

Minha primeira suspeita foi que estaria relacionado a Mona. Que Eva devia ter encontrado coisas que eu escrevi para ela, ou que ela escreveu para mim, e que eu tinha esquecido de pôr fora. "Eva, o que é isso?", eu perguntei, apavorado com a possível resposta. E então Eva abriu a boca, mas som nenhum saiu dela, foi apenas um buraco vazio o que se abriu, um buraco que levava à mulher que tinha sido minha esposa, mas já não era mais, que naquele momento era apenas o espaço vazio que ela mesma havia deixado para trás ao ser arrancada para outro lugar.

Eu vi o carro. Tentaram me impedir, mas eu insisti. Estava em uma oficina, já não me lembro onde, e parecia um objeto frágil que uma criatura gigante tivesse amassado entre as mãos e somente então houvesse se tornado duro, compacto, maciço, com todas as possibilidades e todo o movimento presos no interior de um bloco amassado que não se deixava mais abrir, que nenhuma força no mundo seria capaz de desamassar para que aquilo que havia estado lá dentro pudesse sair e viver outra vez.

Eu vi Ole-Jakob. Tentaram me impedir de fazer isso também. Mas no fim me deixaram entrar no necrotério, onde depois de muitas advertências mostraram-me uma coisa que parecia tão distante de se parecer com qualquer outra coisa que eu tivesse visto antes que, quando vomitei, não foi nem por saber que era ele, mas por causa do que eu tinha visto, tão somente por causa disso. 
Ela parou apenas quando chegou perto de mim. Postou-se ao meu lado, tão próxima que o tecido das nossas jaquetas se roçaram. Passamos um bom tempo assim, sem dizer nada. Eu olhava para ela às escondidas. Havia um ponto de manteiga ou maionese no canto de sua boca. Aquilo me irritou, saber que ela tinha comido. E senti necessidade de contar-lhe sobre Ole-Jakob, sobre quando o vi naquela bancada de metal reluzente. Descrever os olhos, que haviam explodido com o impacto. Descrever o buraco no lugar da boca, que já não existia mais. Como se um monstro em fúria o houvesse dilacerado, eu tinha vontade de dizer, como se um troll verde o tivesse agarrado e espancado até a morte e mutilado o corpo com a força de um gigante.

“Como você está?", eu perguntei.

Ela não respondeu à pergunta; simplesmente continuou olhando para o mar verde do outro lado.

$\mathrm{Na}$ minha boca eu ainda sentia o gosto do vômito.

Um caminhão passou na estrada.

"Estou bem", ela respondeu, dando a impressão de que poderia desabar a qualquer momento.

Quando voltamos ao entardecer, a casa parecia nova. Era como se tivéssemos acabado de nos mudar para lá. Os quadros pareciam recém-pendurados, a cozinha dava a impressão de ser tão nova e tão organizada como o mostruário de uma loja; tudo parecia impessoal e morto, como se ainda não pertencesse a ninguém, simplesmente estivesse lá.

\section{$[\ldots]$}

Tentei dizer qualquer coisa para Stine, para ajudá-la, uma coisa trivial, completamente inofensiva, que trouxesse consigo uma promessa, que pudesse convencê-la de que o perigo havia passado, de que já era possível seguir adiante. Eu queria dizer algo capaz de abrir um novo caminho para ela, minha anjinha, a pessoa que eu amava mais do que qualquer outra no mundo. Mas não me ocorreu nada. E eu tampouco sabia para onde "seguir adiante" poderia levá-la. Além do mais, ela dava a impressão de querer que a deixassem em paz. Aquela introspecção me fez pensar em Ole-Jakob. E então imaginei que ela estaria com ele, em um lugar escondido dentro de si mesma, que aquilo era uma tentativa de 
compreendê-lo, que ela estava em busca de uma resposta, e por isso não queria que a incomodássemos. Que os incomodássemos.

Quando chegou em casa pela primeira vez depois de voltar às aulas, Stine largou a mochila no corredor, no lugar onde eu já lhe havia dito mil vezes que a mochila nunca devia estar, chutou as botas para o meio do tapete e fez uma tentativa fracassada de pendurar a jaqueta, que ficou jogada como um risco de incêndio amorfo em cima do aquecedor que havia logo abaixo do cabide. Eu queria dizer alguma coisa para ela, mas ela subiu direto para o quarto, e em vez de chamá-la de volta eu peguei a jaqueta e a pendurei no lugar, coloquei as botas na prateleira de sapatos, coloquei a mochila em cima do banco sob o espelho e percebi que eu nunca mais havia de repreendê-la por nada. Ela está viva. Ela precisa apenas viver. Depois do que aconteceu, não podemos exigir mais nada dela, a não ser que viva.

As pessoas que conhecíamos ou nos evitavam tanto quanto possível ou faziam o contrário, mal se permitiam afastar-se de nós, apareciam à nossa porta de manhã e de noite, e depois que chegavam não queriam mais sair, como se acreditassem que não havíamos de sobreviver a não ser que estivessem lá para nos segurar de pé. Talvez sentissem como se fosse um dever. Ou ainda tivessem a ideia de estar fazendo parte de um grande acontecimento, o que lhes conferia um papel importante, de maneira que, graças à participação e ao sacrifício oferecidos, pudessem fazer parte da história que a partir de então seria contada sobre a tragédia que se abatera sobre a família Meyer. Era certamente injusto da minha parte, mas eu não conseguia parar de imaginá-las correndo mundo afora depois de nos fazer uma visita e contando as últimas notícias sobre aquela casa enlutada. E eu imaginava a maneira como aumentavam a história ao revelar detalhes para todas as pessoas que não se atreviam a entrar em contato, que restringiam a solidariedade a mensagens de texto ocasionais, tão pífias que eu raramente aguentava lê-las até o fim. Não que as mensagens recebidas cara a cara fossem melhores. Em certos casos, o que tinham no coração era quase imperscrutável; teríamos encontrado frases de sabedoria e palavras de encorajamento mais bem formuladas ao abrir uma revista qualquer. Pode saber, vocês vão sair ainda mais fortes dessa, eu ouvi uma amiga dizer para Eva. Se eu tivesse as forças necessárias eu teria pegado o machado, que ainda estava na TV, cortado o braço dela fora, entregado o braço para ela e dito: Pode saber, você vai sair ainda mais forte dessa.

E eu pensava se não estaria fazendo o mesmo que Stine, buscando o isolamento como uma forma de estabelecer contato com Ole-Jakob. De manter-me no mundo dele. De estar lá até enfim compreender o desejo de ser destruído. 
O tempo passou. Eu vi Eva se reerguer. A tristeza a fortaleceu. Talvez as pessoas que lhe haviam oferecido palavras de encorajamento tivessem razão? Ela se tornou mais dura e aproveitou a admiração recebida por conta da postura altiva. Além disso, notei que os movimentos dela tornaram-se mais ligeiros, na cozinha, no jardim, no mercado, em toda parte, as tarefas eram todas desempenhadas num instante, uma após a outra, como se tudo fosse mais uma peça no quebra-cabeça em que ela trabalhava, um quebra-cabeça que mostrava a nossa vida como tinha sido antes. "Ela é a eficiência em pessoa!", ouvi alguém dizer; e não seria possível dizer de melhor forma. Tudo era feito com mão de ferro, como se aquilo que outrora havia servido de base para as ações dela tivesse sido perdido e restasse apenas fazê-las assim mesmo. Tudo, a não ser dirigir, o que se negava a fazer, a única coisa que havia ficado com ela e com a qual não sabia lidar. Eu quase não a reconhecia. Ela ainda era a mesma, porém transformada a ponto de estar irreconhecível, como uma máquina que tivesse a tarefa de simplesmente aguentar, sem nem ao menos saber por quê. Ela trabalhava. Era isso que ela fazia. O trabalho de uma vida inteira feito sem nenhum tipo de amor, durante o tempo necessário. Eu tinha arrancado dela o amor que ainda lhe restava. Primeiro eu, depois Ole-Jakob, os dois homens em sua vida.

Tentei seguir o exemplo dela, eu voltei a trabalhar e disse a Lise que poderia marcar pacientes em qualquer horário da tarde e da noite sempre que houvesse necessidade, quase sem me permitir intervalos, recebendo de bom grado a tontura, fazendo todo o possível para me sentir exausto, acabado, exaurido, tão trêmulo que às vezes, no final daqueles dias intermináveis, eu correria o risco de perder minha licença se o que eu estava fazendo chegasse aos ouvidos das instâncias competentes.

\section{$[\ldots]$}

Zagreb passou um longo tempo me olhando. Por fim sorriu.

"Dizem que o homem que construiu essa casa para si e para a família descobriu que a mulher o havia traído, ainda durante a construção das fundações, e então enlouqueceu e matou a esposa e os dois filhos do casal. Depois jogou os corpos sob o assoalho do porão. E assim mesmo ele terminou de construir a casa, com duas partes totalmente separadas, e se mudou para uma delas. Logo as coisas devem ter ido mal para ele pela segunda vez, porque ele construiu um aparato curioso, uma pequena gaiola para usar junto do peito, com grades e teto, porém sem fundo. Nessa gaiola ele colocou um rato faminto, e então amarrou a gaiola ao peito de maneira que fosse impossível tornar a desamarrá-la. E então ele deve 
simplesmente ter esperado. Quando o encontraram, ele tinha a boca escancarada. Talvez quisesse ajudar o rato a sair por aquele caminho. As marcas revelavam que tinha estado por toda a casa antes de morrer. Havia poças de sangue em todos os cômodos. O rato foi encontrado na garganta dele. Havia ró́do um bom pedaço do caminho até lá em cima, mas acabou prendendo a cabeça entre o palato mole e as vértebras do pescoço, ficou entalado e não conseguiu avançar mais."

Zagreb riu. "Que fim inusitado! Morto de fome preso em noventa quilos de carne fresca!" Ele passou as duas mãos pelos cabelos. "Parece o enredo de um filme de terror ruim", ele disse, bocejando, como se de repente a conversa o aborrecesse. "Ou aquela sala a respeito da qual Orwell escreveu. O que quer que fosse."

“Mas qual é a sua teoria, afinal?”, eu perguntei.

Mas ele ficou lá sentado, tendo na mão um computador portátil ou um telefone celular que ocupava toda a sua atenção. 